\title{
EXPLORING CONSULTANTS' ROLE IN ERP SYSTEMS IMPLEMENTATIONS
}

\author{
Raniin Chantel Baker and Moutaz Haddara \\ Department of Technology, Krisitiania University College \\ Chrisitian Krohgs gate 32, 0186 Oslo, Norway
}

\begin{abstract}
This paper reviews the extant literature on Enterprise Resource Planning (ERP) systems consultants and investigates if their role change after their implementation in organizations. In ERP implementations, the consultant role is usually divided into different domains. For example, a financial and accounting functional consultants capture the clients' requirements and guide their clients on the best practices and ensure the compliance with standards and accounting principles, while the technical consultants help in the actual technical installation, integration and testing of the system. In general, the primary role of an ERP consultant is to lead an organisation through the transition to an ERP system environment. An ERP consultant is also a person who has various set of skills and expertise across different domains. In this research, we investigate the under-researched area of consultants' roles in the ERP realm. Specifically, we attempt to investigate the changes in consultants' roles before, during, and post ERP adoptions.
\end{abstract}

\section{KEYWORDS}

ERP Systems, Adoption, Consultant Role, Literature Review

\section{INTRODUCTION}

For decades, the enterprise resource planning (ERP) systems have received substantial attention in the research community. ERP systems are large and complex systems, which require knowledge and expertise in many different domains and across various fields of business (Demi \& Haddara, 2018). One of the major cost components in ERP systems are the consultants (Haddara, 2011), therefore it is important to understand their role in the process when a company embarks to deploy an ERP system. In the late 1800s, the consulting role grew with a main focus on technical research areas. After that, there was an increased demand for finance, strategy and organisation consultancy during the early 1900s (McKenna, 1995). By 1990s the consulting growth was primarily focused on both information technology (IT) and strategy development and advice (Wikipedia Contributors, 2019). During the dot-com bubble in 2001, the consulting industry stagnated for a short period and rose again after 2003 (McKenna, 2003). In our modern world, with the rise of social media, cloud-based implementations and Internet of thing (IoT) technology emergence, the consultant role has morphed and changed. Traditionally, the ERP consultants' role was mainly to technically implement systems that meet the organizations' demands, but now the consultant's role is more focused into guiding organizations on how to use these systems in the best practice possible (McKenna, 2003).

The objective of this paper is to review the consultants' role before, during and after ERP systems go-live through a focus on consulting history and change management and the role an ERP consultant plays in a radical redesign of an organisation. One of the most important benefits of an ERP consultant is the ability to transfer knowledge from consultant to staff, which if done correctly, will enable companies to become self-reliant. These topics were the most discussed in the selected literature chosen for this review. In order to increase the comprehension of the ERP consultant role, two interviews with two consultants in a leading international ERP vendor in Norway were conducted.

The rest of the paper is organized as follows. The next section presents the research methodology adopted in this research. Section 3 illustrates an overview of the selected articles. Section 4 demonstrates the main findings, followed by a discussion in section 5. Finally, a conclusion is provided in section 6 . 


\section{RESEARCH METHODOLOGY AND ARTICLES OVERVIEW}

In extant literature, a gap exists in research on post-ERP implementations in general (Haddara \& Hetlevik, 2016), and specifically on the consultant's role before versus post the ERP go-live. The objective of this paper is to review the ERP consultant's role before, during and after the ERP system is up and running.

Literature reviews exemplify a well-established method for accretion of existing knowledge within a domain of interest. In this article we have adopted a systematic review method (Watson, 2015). This method is ruminated by implementing perspicuous procedures and conditions, which potentially minimize researcher's bias (Bryman, 2012). The search for papers included in this literature review was conducted using Google Scholar. At first, the searches in the databases were narrowed by looking at articles published in renowned journals in the field of information systems. The journals selected were primarily the basket of eight journals listed in the "Senior Scholars' Basket of Journals" published on the Association for Information Systems (AIS) website. The search keywords used when researching papers were "Consultant ERP", and "Consultant Enterprise Resource Planning System". In addition, other keywords were also used in conjunction with the previous key terms, like "implementation" "post-implementation", "Selection", "adoption", and "shakedown phase". In addition, only peer-reviewed articles written within the period 1995-2019 were included in this research. The mentioned criteria resulted in a very low number of articles. So, in order to broaden the scope of the literature review, we then extended the search keywords to include more broad combinations of terms like " Consultant Enterprise Systems", "Consultant role in Information Systems", "Consultant History" and others. After identifying some more articles, we have also scanned the references of these articles to pinpoint more research that we might have overlooked. This also made us able to review more studies, which some have been published in conferences/journals outside the IS field, like change management. This resulted in a significant number of article results that was more than 250 potential articles. The authors then glanced through the articles' abstracts and conclusions and have excluded various papers, which were not directly addressing the impact/role of consultants during ERP systems implementations. Thirty-two candidate articles remained after the first iteration. In the next phase, the authors read all of the 32 articles, which resulted in further exclusion of some papers, which the content turned out to be out of scope of this review. The authors then read the papers and classified them by their main topic in focus as shown in figure 1 . It is important to note that some articles covered more than on topic or theme. In total, 18 articles were identified and reviewed in this research, including more general papers on the consultants' role in information systems' adoptions, and consultation history in organizations. As mentioned earlier, the focus of this research is on consultant role when a company embarks to deploy an ERP system. The consultant' role in ERP implementation depends on the level of involvement of the consultant in a project. The more control a client company has, the less involved a consultant is (Heines and Goodhue, 2000). Having said that, it depends on the vendor, the client and the implementation partner, on how they can agree on the terms.

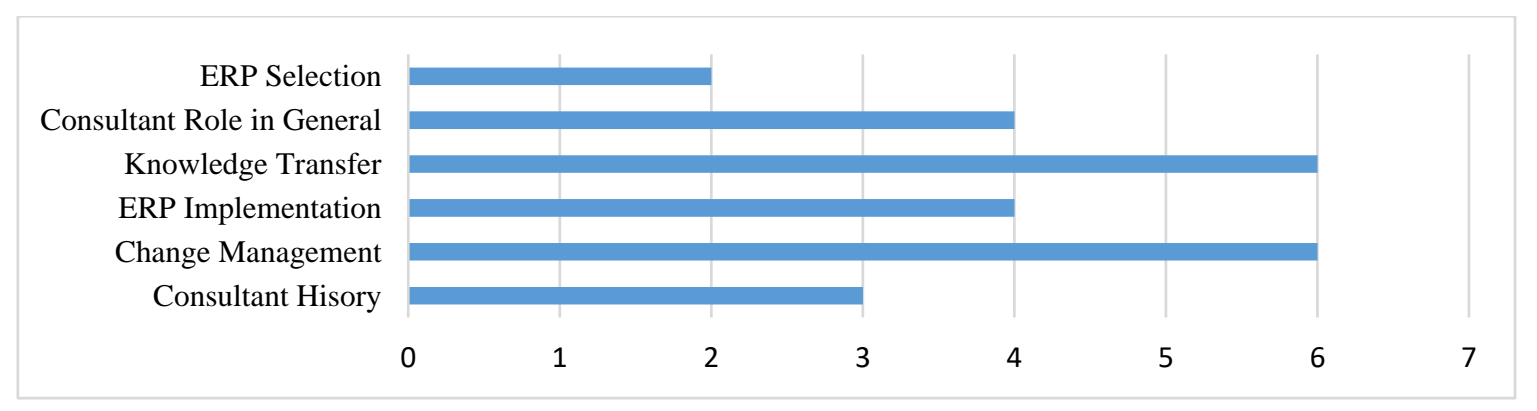

Figure 1. An Overview of Main Themes and Number of Reviewed Articles

Additionally, the first author conducted two qualitative interviews (Bryman, 2012) with two ERP consultants in an international ERP vendor in Norway. The interviews were digitally recorded, and transcribed, and relative sections were then included in this article. The participation of the ERP consultants aided in shedding more light on the modern ERP consultant role. The interview questions that were asked were mainly based on the ERP lifecycle model (Esteves \& Pastor, 1999), and other topics like change management, and scope and commitment. The main questions that were asked were: 
- What is the main role of ERP consultants?

- Does the consultant's role change after the ERP go-live?

- $\quad$ Do you help with the company's strategy? Alternatively, is it just training the system?

- Do you decide the role you undertake when starting a project or does the client decide your role?

\section{FINDINGS}

In general, the consultant's work is divided into different expertise and areas, like finance and accounting, human resources, technical implementation, and others. While ERP systems' literature is rich, however, papers focusing on the role of consultants in adoption projects are rare. Thus, identifying papers that could cover our review objectives was challenging regarding the limited literature about the topic. Our findings include the background history of consulting, the role of consultancy in different areas, and the role of consultancy in the ERP domain in specific. Table 1 presents our findings from the 18 sources in a chronological order from 1995 to 2018 . The majority of the articles suggest that the role that consultants play is crucial as it is one of the success factors for implementing an ERP, but not much of these articles go in-depth on the exact role of these ERP consultants. However, the interviews provided more background information that compliments this paper.

Table 1. Overview of Articles and their Main Focus

\begin{tabular}{|c|c|}
\hline Article & Short Description \\
\hline McKenna (1995) & $\begin{array}{l}\text { This paper describes the history of consulting, with a focus on management consulting. It also } \\
\text { argues for the reasons that led to the growth of the consulting business after } 1920 \text {. }\end{array}$ \\
\hline $\begin{array}{l}\text { Bessant \& Rush } \\
\text { (1995) }\end{array}$ & $\begin{array}{l}\text { This article views the consultants' role regarding process transfer and the policy mechanism } \\
\text { which enable it to proceed effective. It focuses on the role of consultancy in the innovation } \\
\text { process within organizations. The authors present ten types of consultancy from the traditional } \\
\text { consultancy aspect. }\end{array}$ \\
\hline Canback (1999) & $\begin{array}{l}\text { The article presents the history of consultancy and argues why management consulting is so } \\
\text { important and explains it through the transaction cost theory. Moreover, the author develops } \\
\text { illustrates potential scenarios for the future industry evolution and management consulting. }\end{array}$ \\
\hline $\begin{array}{l}\text { Esteves \& Pastor } \\
\text { (1999) }\end{array}$ & $\begin{array}{l}\text { This paper presents a suggested ERP life-cycle model that includes } 6 \text { phases, which an } \\
\text { organization goes through during the adoption of ERP systems. The paper also illustrates four } \\
\text { dimensions in which they shed the light on the consultant's role during the implementation phase } \\
\text { and change management efforts. }\end{array}$ \\
\hline $\begin{array}{l}\text { Westrup \& Knight } \\
\text { (2000) }\end{array}$ & $\begin{array}{l}\text { This paper investigates how consultants' change and shape the way in which ERP Systems are } \\
\text { seen and implemented by viewing five types of organizational knowledge. }\end{array}$ \\
\hline $\begin{array}{l}\text { Adam \& } \\
\text { O'doherty (2000) }\end{array}$ & $\begin{array}{l}\text { This article examines the key relationship between client organizations and their ERP } \\
\text { implementing partners, in particular SMEs in Ireland. }\end{array}$ \\
\hline $\begin{array}{l}\text { Heines \& } \\
\text { Goodhue (2000) }\end{array}$ & $\begin{array}{l}\text { The paper investigates the role of the vendor, the organization and the consultants in } \\
\text { implementing an ERP system and the knowledge impact that these three parties have on the } \\
\text { implementation. }\end{array}$ \\
\hline $\begin{array}{l}\text { Caldas \& Wood } \\
(2000)\end{array}$ & $\begin{array}{l}\text { The paper discusses how consultants should enter the ERP world and how they would be a big } \\
\text { part of ERP implementation. in the paper also presents the advantages and cons of ERP } \\
\text { consultancy. In addition, the paper discusses whether ERP consultants should work on widening } \\
\text { the project's scope to sell more services, or mainly focus on their main tasks. }\end{array}$ \\
\hline
\end{tabular}




\begin{tabular}{|c|c|}
\hline Pereira (2001) & $\begin{array}{l}\text { The article sheds light on five important roles that interplay between use of information systems } \\
\text { and organizational change. }\end{array}$ \\
\hline $\begin{array}{l}\text { Askenäs \& } \\
\text { Westelius (2003). }\end{array}$ & $\begin{array}{l}\text { The article examines five roles in the use ERP systems that provides organizational change. One } \\
\text { of them is the consultant role in change management. }\end{array}$ \\
\hline $\begin{array}{l}\text { McKenna et al. } \\
\text { (2003) }\end{array}$ & $\begin{array}{l}\text { The article investigates modern management consulting activities in the era of globalization. } \\
\text { They argue that some scholars claim that management consultants aid when there is a shortage } \\
\text { of internal expertise within organizations. Otherwise, other researchers argue that consultants } \\
\text { serve as scapegoats in situations that require difficult decisions, as a tool for risk sharing. }\end{array}$ \\
\hline $\begin{array}{l}\text { Zimmerman \& } \\
\text { Smedley (2006) }\end{array}$ & $\begin{array}{l}\text { This article discusses the implementation of ERP systems and how organizations should adjust to } \\
\text { changes. The paper focuses on the role of consultants in knowledge transfer and management. }\end{array}$ \\
\hline $\begin{array}{l}\text { Sturdy et al. } \\
\text { (2009) }\end{array}$ & $\begin{array}{l}\text { The article discusses consultancy and knowledge. Examines two dominant images of the role of } \\
\text { consultants. The innovator and legitimating client knowledge. }\end{array}$ \\
\hline Koh et al. (2009) & $\begin{array}{l}\text { The paper argues about the necessity of investing in training and consultancy for reaching a } \\
\text { successful implementation of ERP systems in SMEs. }\end{array}$ \\
\hline Lunenburg (2010) & $\begin{array}{l}\text { The article highlights the importance of consultants as change agents. It divides them into } 4 \\
\text { types, with } 3 \text { roles and } 10 \text { characteristics. }\end{array}$ \\
\hline $\begin{array}{l}\text { Christensen et al. } \\
\text { (2013). }\end{array}$ & $\begin{array}{l}\text { The authors discuss how tech-disruption has caused changes in consultants' role. They also } \\
\text { argue that the consultation industry is now faced with same disruption forces that are starting to } \\
\text { impact the consulting industry, with intense implications for its future. }\end{array}$ \\
\hline Haddara (2014) & $\begin{array}{l}\text { This paper demonstrates the consultants' role during the ERP system selection phase within } \\
\text { organizations. The article also provides evaluation criteria for ERP system selection. }\end{array}$ \\
\hline $\begin{array}{l}\text { Hustad et al. } \\
\text { (2016) }\end{array}$ & $\begin{array}{l}\text { The article presents a case study in which it demonstrates the role of functional consultants in } \\
\text { ERP system customizations. In addition, the article discusses the impact of customizations on } \\
\text { organization in case of misalignment with clients' requirements. }\end{array}$ \\
\hline Haddara (2018) & $\begin{array}{l}\text { The paper provides a case study on ERP selection efforts within a multinational organization. } \\
\text { The paper argues on how international data exchange regulations (e.g. GDPR) can affect the } \\
\text { consultants' selection process and criteria. }\end{array}$ \\
\hline
\end{tabular}

\subsection{The Consultants' Role Throughout History}

Greiner and Metzger (1983) defined consulting as an advisory service based on a contract and provisioned to organizations by experienced and qualified individuals who can aid clients in an objective and autonomous manner. Also, they assist client organizations in identifying their problems and requirements, recommend a solution to these problems, and aid in the enactment of solutions (Greiner \& Metzger, 1983).

In specific, an ERP consultant is either an independent consultant or an employee who is employed in a company that is hired to do any of the following activities: select, implement, upgrade, or support an ERP system. The main role of an ERP consultant is to help organizations move from the current state to an ERP system. An effective ERP consultant is capable of understanding clients' business process, in order to establish where ERP systems would be most beneficial (King, 2012). Figure 2 below, depicts a timeline of the important events in the consulting world, gathered through the various articles that were reviewed in this paper. In general, the topics from the selected articles are much related to the general consultant's role within organizations. Often each vendor, consultancy firm or client agree on terms on the level of involvement from each partner regarding the modules to be implemented, implementing methodology, level of customization, and change management. Change management in particular was the focus of several papers in literature. Change management is required when an organisation is going through a radical redesign of their process 
and IT/IS infrastructure. This dimension refers to the body of knowledge that is used to guarantee that a compound change, like that associated with an implementation of a large system, obtains the right results, within the planned deadline, and at the estimated budget (Holland \& Davis, 1998 in Esteves \& Pastor, 1999). Opportunities for management consulting arise not only in IT-related consulting but also in change management (Miguel Caldas, 2000). The ERP consultant plays a large role in change management during ERP adoption projects (Lunenburg, 2010). An ERP consultant also helps with the planning, implementing and following-up changes in the ERP system during the project (Westrup and Knight, 2000). ERP projects are complex, and introduce changes in business processes and organizational structures. Thus, they require reliance on much different expertise, often found outside the client organisation (McKenna et al., 2003). In the ERP system adoption project, the environment of the project usually involves three parties: the client - the company that needs the ERP, the vendor, which sells the ERP software, and the consultant/the implementation partner. In some cases, the company does not need a partner; in which the vendor will provide consultants that could help with the implementation process in that case (Haddara, 2018). The need for consultants that can guide the company through the implementation process is critical, whether it comes from the vendor's or the implementation partner's side (Haddara, 2014).

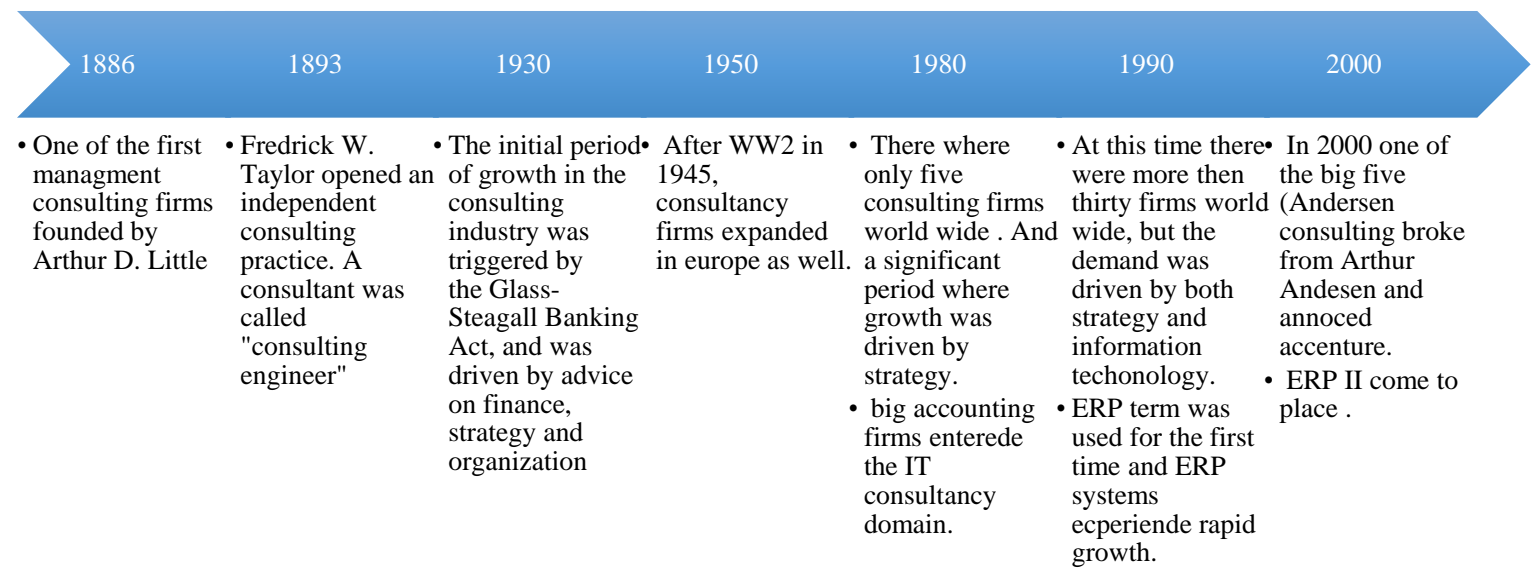

Figure 2. Milestones in the Consulting World's History

\subsection{ERP Life Cycle Phases - Implementation- The Impact of the Consultant}

When implementing an ERP system, it is necessary to adopt a life-cycle model. This is important for companies to know the status of the project, and to know which phase they are currently at, and also to be able to calculate the time, the needs and budget for consultants. The phases of the ERP life-cycle consist of several stages that an ERP system goes through during its whole life within the hosting organisation (Esteves and Pastor, 1999). One of them is the selection phase. The selection phase is the stage in which the organization evaluates the different ERP packages and vendors who meet its needs, budget, and requirements (Haddara, 2014). It is considered as a critical phase, as selecting the wrong ERP may lead to complete project failures or cancellations (Elragal \& Haddara, 2013). Another important stage is the implementation phase, which is the actual installation of the system. This phase consists of the customisation or parameterisation and adaptation of the ERP package acquired according to the needs of the organisation. Usually, this phase is accomplished with the help of consultants who provide implementation methodologies, know-how, and adequate training (Esteves and Pastor, 1999). In the implementation phase, the impact of the consultant is imperative. Since an ERP project can take up to two years, especially large projects, the implementation partner usually has a "hands on" involvement. The consultants will solve issues regarding the ERP system and aid in ensuring that the implementation process is progressing as planned. Hence, the level of the consultants' experience and knowledge play a paramount role in applying this knowledge to the client organisation (Westrup and Knight, 2000). 


\subsection{Knowledge Transfer and Information Usage}

Knowledge transfer in organization is a very important process during and post ERP implementations (Haddara \& Hetlevik, 2016). Most of the studies reviewed discuss knowledge transfer in organizations and look at the consultant as knowledge transfer medium and catalyst. Knowledge management (KM) is the process of creating, sharing, using and managing knowledge and information of an organisation (Girard, 2015). It refers to a multidisciplinary approach to achieving organisational objectives by making the best use of knowledge, and can be achieved through different types of mechanisms, like communities of practice (Haddara \& Hetlevik, 2016). Knowing how to create information that people can use and rely on is within an area that has come to be known as knowledge management (Zimmerman\& Smedley, 2006). Similarly knowing how to transfer knowledge to others is an essential part of a consultant's role. From the KM perspective, consultants now work across different expertise when hired to help implement an ERP system, using for instance their IT- and financial skills so the client can benefit from using the ERP system in the best practice feasible. Zimmerman\& Smedley (2006) support that argument and stress about the importance of the consultant's role in the implementation and post-implementation phases of the ERP system. The consultant should not only have knowledge concerning the system but also have communication skills, good language capability, industry knowledge and business analytical skills (Wong et al., 2005). Having and managing knowledge across these different domains help the consultant to perform in the best way possible.

\subsection{Other Findings}

The findings here are from the interviews conducted with two ERP consultants. One consultant was asked the main consultant role in ERP implementations. "Before ERP adoptions, companies usually used multiple systems, and these may have functioned in isolation (like a silo) and therefore did not provide a comprehensive overview or overall image of the company's value chain. Now with ERP systems, one will be able to look at the entire company's value chain, so in this way, more consultants with different backgrounds and various expertise will be needed to implement a proper ERP system project." (Consultant 1). Another question was if the consultant usually aids in the client's organization strategy. "We do not help the in the company's strategy (as far as I know), but what we do is to emphasise that switching systems must be anchored from top management level and down to the users of the system. Since we have a standardised system, we map how the processes in the company work and what changes they should make in order to work optimised in our system. In addition to training, as I would say it is very important." (Consultant 2). Traditionally, the consultant has served as a bridge between information and knowledge. Do you feel that this role is still existent during and post ERP implementations? "I would say that this remains to some extent. Experienced consultants who work with us usually have the knowledge and previous experience with what works and what does not work. In this way, a consultant may in some cases act as a "counsellor" for any company that may need guidance or best practice advice." (Consultant 2).

One of the consultants (Consultant 1) elaborated that "each consultant gets assigned a module that they are going to specialise in. Those who work with payroll and accounting modules usually have a background in finance, but not all of them can advise on the economic situation of an organisation. While consultants who work with import and integration, as I do, could have a different area of expertise. However, since an ERP system is a standard database serving multiple functional areas in an organisation, basic financial skills are always an advantage." Furthermore, both consultants explained that when initialling an agreement with an organisation, the client and the consultant work together from the implementation phase all the way to "go-live" phase. The consultant will also be the client's contact person as long as the customer relationship is active. However, this will vary from consultant level and area of expertise; often the principal consultant will participate in the entire journey. The presales consultants who are part of the sales phases will keep in contact with the client until the customer goes live. Part of the preparation for the presales consultant is how to precisely map out what is not working, why it is not working and how implementing the ERP system can solve it. Performance improvement is defined in many ways, but often a customer will get a lower cost, increased control and overview, and processes go faster than before, resulting in saved hours.

\section{DISCUSSION}

The objective of this paper was to examine the consultant's role in ERP adoption projects. Since the birth of consultancy in 1886, the consultant role in general did not face radical changes. Various articles view a 
consultant as an expert "outsider", helping organisations use internal information in the best way possible. Due to World War Two, and the growth of military contractors and the subsequent economic growth, the number of consulting firms grew from $400-1000$, in 1940-1950. By 1950, and IT consulting grew as mainframe computers began to emerge (McKenna, 1995). A consultant's job was much involved in strategic planning, financial advice and accounting. The big five, now the big four entered the IT consulting arena around 1980. Even at that time IT consultants also were called "consulting engineers" and helped with system installations. Until 1999, there remained a certain doubt about the consultant growth, even though organisations such as the big five had adopted consulting in finance, strategy and IT consultancy domain. Canback (1999) argues that many sceptics were not sure if consultants did add real value, while some companies kept using consultants as outsider experts. However, in literature the consultancy is usually viewed as a critical success factor in ERP system implementations (Haddara, 2018).

So, what do ERP consultants actually do? According to our findings, ERP consultants aid organizations during the various ERP lifecycle phases. From the initial phases like the adoption and ERP selection phases, all the way to the post implementation phases. Hence, an ERP consultant should have different areas of expertise and also different set of skills. The skills set should include communication, conflict management, and analytical skills, among others. The role played by consultants in ERP implementations has also been questioned in some papers, and the reason for that might be that the tasks of a consultant could somehow be unclear in some situations, or sometimes the consultants are viewed as scapegoats for clients facing complex decision. In addition, there could be a mismatch between the client and the consultant, as demonstrated through the agency and transaction cost theories (Bahli \& Rivard, 2003). As illustrated in the interviews, each consultant takes part in different phases. We could look at consulting as a cycle, which includes presales consultants that pitch the idea to a client, and other consultants involved in contracting, information gathering, analysis and reporting, action planning, and other serve as the implementation team (that is also divided by their area of expertise). It is important to keep in mind that an ERP consultant can be hired for an extended period, unlike the traditional management consultant. It is thus important for clients to choose the right implementation partner as choosing the ERP system that fits the company. Experienced consultants can play an essential role in improving organisations if both parties are entirely engaged in the process.

As for the consultant, they have to know that they are a part of a radical change that is about to happen for the client company. Consultants are expert outsiders with a new and fresh view, and their job is to make that change as sophisticated as possible. They are sitting with the knowledge, and the information about the system and it is their job to apply that knowledge and share that information in the best way possible.

\section{CONCLUSION}

There are different descriptions in the term consultant, to this date, the consultant's role has become more technical. Pre-ERP implementations, various department and divisions often had their systems and processes isolated. An ERP system in the broader definition, will integrate data and processes, and make information for the entire business available. As for an ERP consultant, it is not just about knowing technology, finance, or logistics. An ERP consultant also needs to be a ripple of change in the business processes in the company. Along with being a catalyst between business and technology, an ERP consultant should also need to manage knowledge transfer since implementing an ERP system can be a significant change for a company. During this research attempted to gain a better understanding on the various roles a consultant can play in the ERP systems life-cycle. Due to the scarce research in the ERP consultancy area, it is then recommended that other studies investigate the ERP consultancy domain in more depth, and also evaluate the impact of new technologies, like cloud ERP systems on the ERP consultants' roles.

\section{REFERENCES}

Adam, F., and O'Doherty, P. "Lessons from enterprise resource planning implementations in Ireland-towards smaller and shorter ERP projects." Journal of information technology15.4 (2000): 305-316.

Askenäs, L., and Westelius, A. "Five roles of an information system: a social constructionist approach to analyzing the use of ERP systems." Proceedings of the twenty first international conference on Information systems. Association for Information Systems, 2000.

Bahli, B., \& Rivard, S. (2003). The information technology outsourcing risk: a transaction cost and agency theory-based perspective. Journal of Information Technology, 18(3), 211-221. 
Bessant, J., and Rush, H. "Building bridges for innovation: the role of consultants in technology transfer." Research policy 24.1 (1995): 97-114.

Bryman, A. Social research methods: OUP Oxford; 2012.

Caldas, M. P., and Wood, T. "How consultants can help organizations survive the ERP frenzy." Paper submitted to the Managerial Consultation Division of the Academy of Management, Chicago (1999).

Canback, S. "The logic of management consulting: Part 2." Consulting to Management 10.3 (1999): 3.

Christensen, C. M., Wang, D., and Bever, D. V. "Consulting on the Cusp of Disruption." Harvard business review91.10 (2013): 106-114.

Demi, S., \& Haddara, M. (2018). Do Cloud ERP Systems Retire? An ERP Lifecycle Perspective. Procedia Computer Science, 138, 587-594.

Elragal, A., \& Haddara, M. (2013). The impact of ERP partnership formation regulations on the failure of ERP implementations. Procedia Technology, 9, 527-535.

Esteves, J., and Pastor, J. "An ERP lifecycle-based research agenda." 1st International Workshop in Enterprise Management \& Resource Planning. 1999.

Greiner, L. E., \& Metzger, R. O. (1983). Consulting to management. Prentice-Hall.

Girard, J., and Girard, J. "Defining knowledge management: Toward an applied compendium." Online Journal of Applied Knowledge Management 3.1 (2015): 1-20.

Haddara, M. (2011). ERP adoption cost factors in SMEs. In European and Mediterranean Conference on Information Systems (EMCIS 2011), Athens, Greece.

Haddara, M. (2014). ERP selection: the SMART way. Procedia Technology, 16, 394-403.

Haddara, M. (2018). ERP systems selection in multinational enterprises: a practical guide. International Journal of Information Systems and Project Management, 6(1), 43-57.

Haddara, M, \& Hetlevik, T. (2016). Investigating the Effectiveness of Traditional Support Structures \& Self-organizing Entities within the ERP Shakedown Phase. Procedia Computer Science, 100, 507-516.

Heines, N. M., and Goodhue, L. D. ERP Implementations: "The role of implementation partners and knowledge transfer" Av Information Resources Management Association. International Conference (2000): 34-40.

Hustad, E., Haddara, M., \& Kalvenes, B. (2016). ERP and organizational misfits: An ERP customization journey. Procedia Computer Science, 100, 429-439.

King, A. (2012). What is an ERP Consultant? Retrieved from ERP Software Blog website: https://www.erpsoftwareblog.com/2012/06/what-is-an-erp-consultant/

Koh, S. C. L., A. Gunasekaran, and J. R. Cooper. "The demand for training and consultancy investment in SME-specific ERP systems implementation and operation." International journal of production economics 122.1 (2009): 241-254.

Lunenburg, F. C. "Managing change: The role of the change agent." International Journal of Management, Business and Administration 13.1 (2010): 1-6.

McKenna, C. D. "The origins of modern management consulting." Business and Economic History (1995): 51-58.

McKenna, C., Djelic, M. L., \& Ainamo, A. (2003). Message and Medium: The Role of Consulting Firms in Globalization and its Load Interpretation in: Globalization and Institutions, chapter 4 Edward Elgar Publishing.

Pereira, R. E. "An Action-Oriented Perspective of Information Systems in Organizations." INFORMING SCIENCE4.3 (2001): 105-114.

Sturdy, A., Clark, T., Fincham, R., and Handley, K. "Between innovation and legitimation-boundaries and knowledge flow in management consultancy." Organization 16, no. 5 (2009): 627-653.

Watson, R. T. (2015). Beyond being systematic in literature reviews in IS. Journal of Information Technology, 30(2), 185-187.

Werr, A. (2005). Consultant supported ERP implementation-a learning opportunity. Stockholm School of Economics. Stockholm. (SSE/EFI Working Paper Series in Business Administration, 2005: 3).

Westrup, C., and Knight, F. "Consultants and Enterprise Resource Planning (ERP) systems." ECIS 2000 Proceedings (2000): 178.

Wikipedia contributors. (2019, March 16). Management consulting. In Wikipedia, The Free Encyclopedia. Retrieved March 26, 2019, from https://en.wikipedia.org/w/index.php?title=Management_consulting\&oldid=888089363

Wong, A., Chau, P. Y. K., Scarbrough, H., \& Davison, R. (2005). Critical failure factors in ERP implementation. In 9th Pacific Asia Conference on Information Systems: I.T. and Value Creation, PACIS 2005

Zimmerman, E., and Smedley, J. "ERP Implementations-a never ending story?." IRIS 29, Paradigms Politics Paradoxes, 29th Information Systems Research Seminar in Scandinavia, August 12-15 2006, Helsing $\phi r$, Denmark. IRIS, 2006. 